\title{
A comprehensive analysis of cleaner production policies in China
}

\author{
Huatao Peng and Yang Liu \\ Journal Article
}

\section{Tweet}

N.B.: When citing this work, cite the original article.

Original Publication:

Huatao Peng and Yang Liu, A comprehensive analysis of cleaner production policies in China, Journal of Cleaner Production, 2016. 135, pp.1138-1149.

http://dx.doi.org/10.1016/j.jclepro.2016.06.190

Copyright: Elsevier

http://www.elsevier.com/

Postprint available at: Linköping University Electronic Press

http://urn.kb.se/resolve?urn=urn:nbn:se:liu:diva-131869

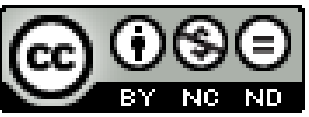




\section{elsevier_JCLP_7561}

\section{A comprehensive analysis of cleaner production policies in China}

\section{Huatao Peng}

penghuatao@126.com

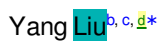

yang.liu@liu.se

yang.liu@uva.fi

aSchool of Management, Wuhan University of Technology, 122 Luoshi Road, Hongshan District, Wuhan, 430070, People's Republic of China

bSchool of Electrical and Electronic Engineering, Hubei University of Technology, No.1 Lizh Rod28 Nanli Road, Hongshan District, Wuhan, 430068, People's Republic of China

cDepartment of Management and Engineering, Linköping University, SE-581 83, Linköping, Sweden ${ }^{d}$ Department of Production. University of Vaasa. PL 700.65101 Vaasa. Finland

${ }^{*}$ Corresponding author. School of Electrical and Electronic Engineering, Hubei University of Technology, No.1 Lizhiroad28 Nanli Road, Hongshan District, Wuhan, 430068, People's Republic of China.

\section{Abstract}

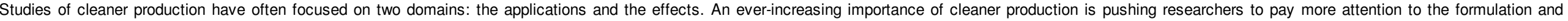

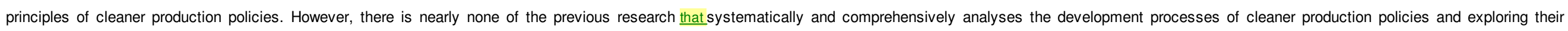

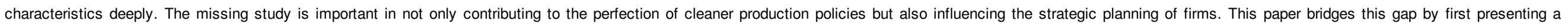

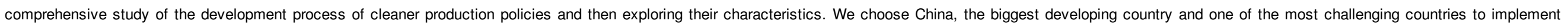

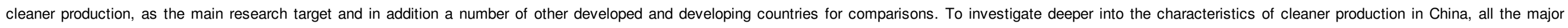





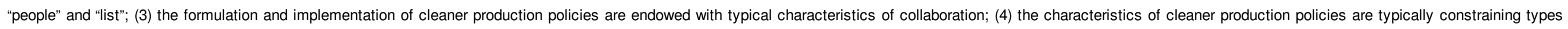
that evidently guide and regulate the behaviours of firms. This paper contributes as a general important reference of cleaner production policies for governments and firms especially in developing countries.

Keywords: Cleaner production; Policies; Content analysis; China

\section{Introduction}

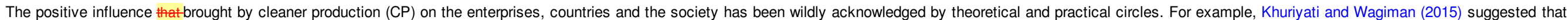



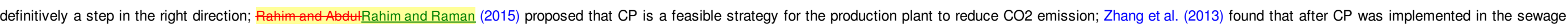

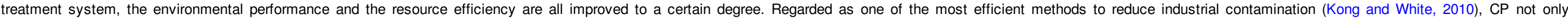

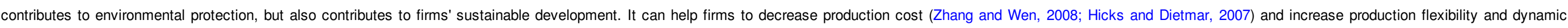

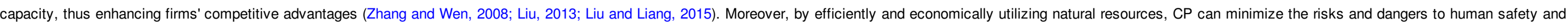

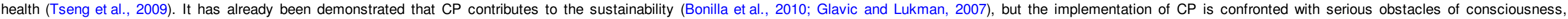

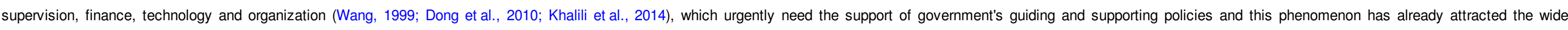
attention of theoretical and practical circles. 


\section{elsevier_JCLP_7561}

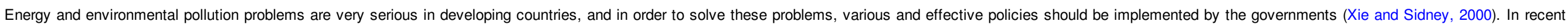

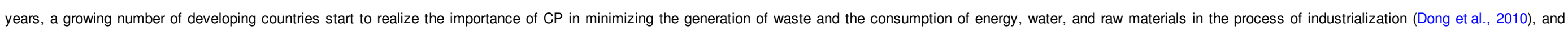



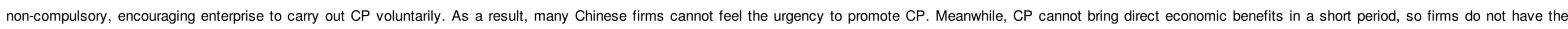






subsidies for those firms that



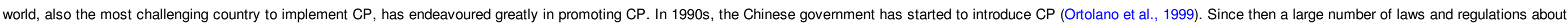

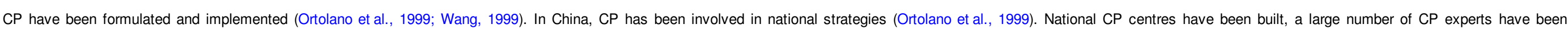

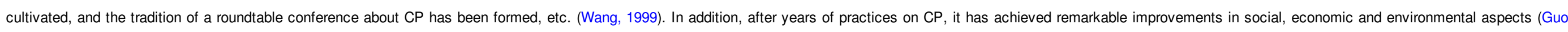

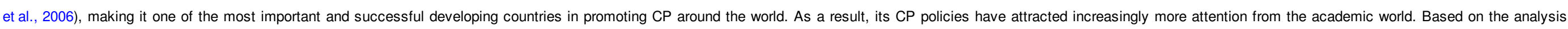
above, this study selects China as the primary research subject.

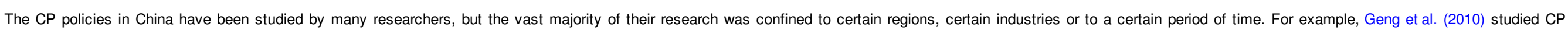

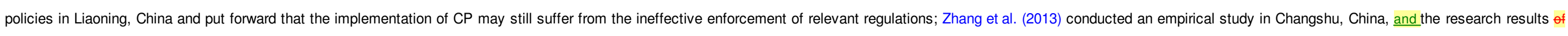

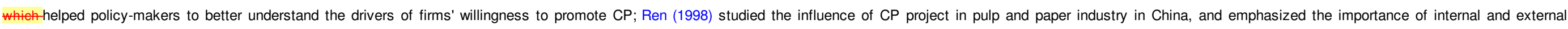

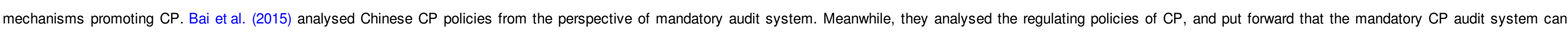





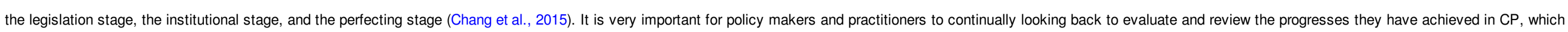

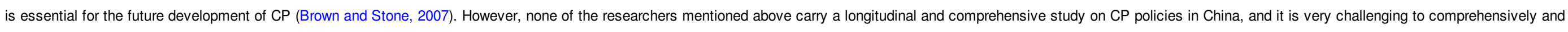

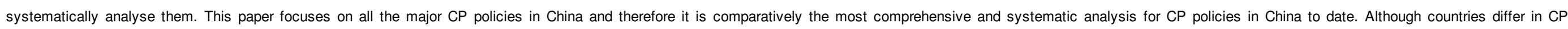

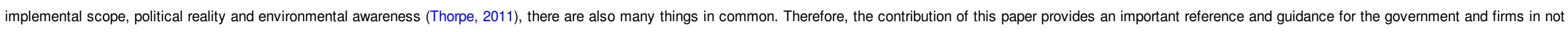
only China but also other developing countries.

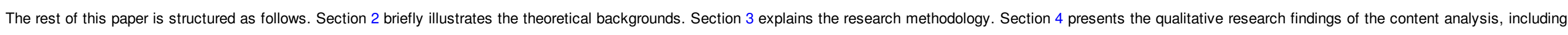

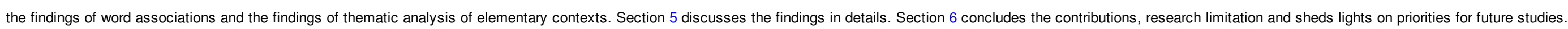

\section{Theoretical backgrounds}

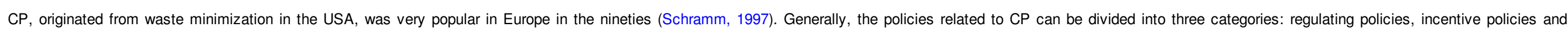

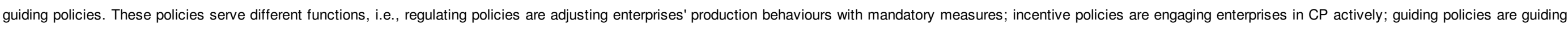
the modes, methods, and directions of $\mathrm{CP}$.

\subsection{Regulating policies}

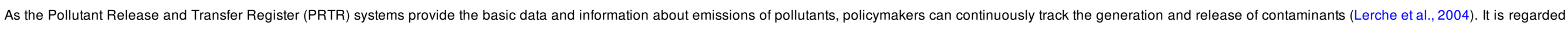



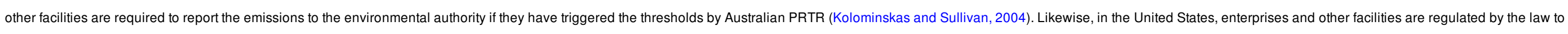




\section{elsevier_JCLP_7561}

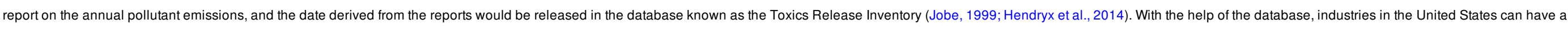

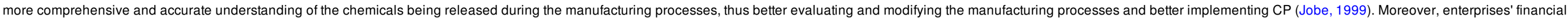



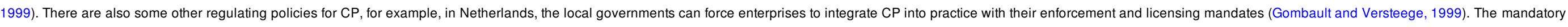

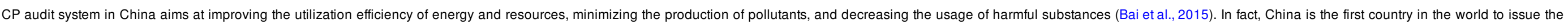
Cleaner Production Promotion Law to force enterprises and other organizations to carry out CP.

\subsection{Incentive policies}



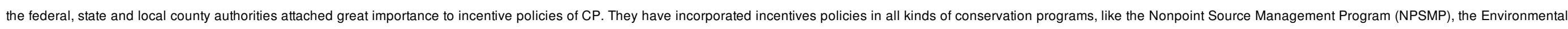



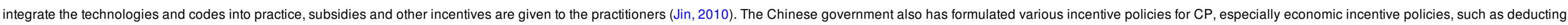

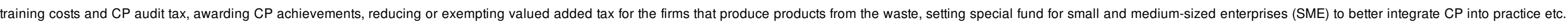

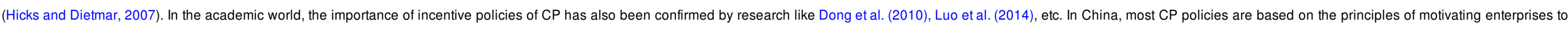

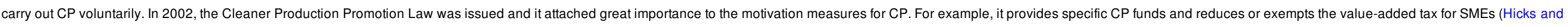
Dietmar, 2007).

\subsection{Guiding policies}

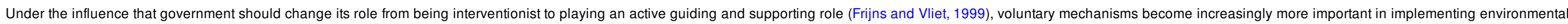



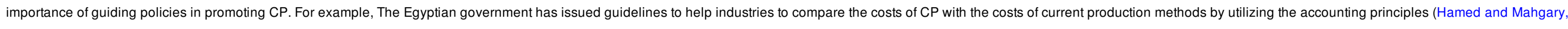



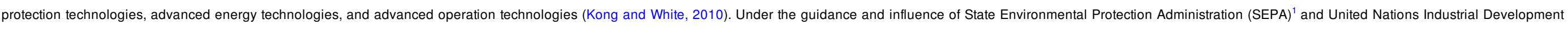



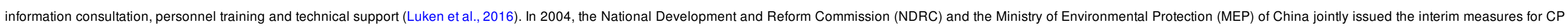
audit. Moreover, they worked together to promote CP training, and to provide CP audit information and technical support (Bai et al., 2015).

\section{Research methodology}

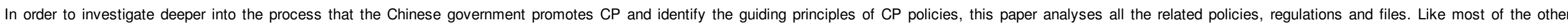

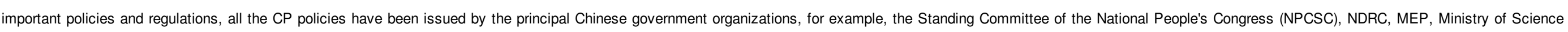


the official website of the issuing organizations as shown in Table 1.

Table 1 Policies, regulations and governing documents of $\mathrm{CP}$ in China.

\begin{tabular}{|c|c|c|c|c|c|}
\hline File name & $\begin{array}{c}\text { Issuing } \\
\text { organization }\end{array}$ & $\begin{array}{c}\text { Reference } \\
\text { number }\end{array}$ & Issuing date & Background & Policy classification \\
\hline $\begin{array}{l}\text { Notice of } \\
\text { Opinions for } \\
\text { Promoting } \\
\text { CP issued by } \\
\text { SEPA }\end{array}$ & SEPA & No.232 & Apr. 14, 1997 & $\begin{array}{l}\text { In order to } \\
\text { realize the } \\
\text { overall } \\
\text { objectives of } \\
\text { promoting CP }\end{array}$ & Comprehensive policies \\
\hline
\end{tabular}




\section{elsevier_JCLP_7561}

\begin{tabular}{|c|c|c|c|c|c|}
\hline & & & & $\begin{array}{l}\text { in the 9th Five } \\
\text { Year period }\end{array}$ & \\
\hline $\begin{array}{l}\text { Laws for } \\
\text { Promoting } \\
\text { CP of } \\
\text { People's } \\
\text { Republic of } \\
\text { China }\end{array}$ & NPCSC & $\begin{array}{l}\text { Decree of } \\
\text { the } \\
\text { President } \\
\text { of the } \\
\text { People's } \\
\text { Republic } \\
\text { of China, } \\
\text { No.72 }\end{array}$ & Jun.29, 2002 & $\begin{array}{l}\text { In order to } \\
\text { promote CP, } \\
\text { increase } \\
\text { resource use } \\
\text { efficiency, } \\
\text { decrease } \\
\text { pollution, } \\
\text { protect } \\
\text { environment } \\
\text { and human } \\
\text { health, and } \\
\text { realize the } \\
\text { sustainable } \\
\text { development } \\
\text { of economy } \\
\text { and society. }\end{array}$ & Guiding policies \\
\hline $\begin{array}{l}\text { Opinions for } \\
\text { Implementing } \\
\text { Laws for } \\
\text { Promoting } \\
\text { CP }\end{array}$ & SEPA & No. 60 & Apr.4, 2003 & $\begin{array}{l}\text { In order to } \\
\text { implement } \\
\text { Laws for } \\
\text { Promoting CP, } \\
\text { execute the } \\
\text { responsibilities } \\
\text { of SEPA and } \\
\text { promote firms } \\
\text { to carry out } \\
\text { CP. }\end{array}$ & Comprehensive policies \\
\hline $\begin{array}{l}\text { Opinions for } \\
\text { Accelerating } \\
\mathrm{CP}\end{array}$ & $\begin{array}{l}\text { NDRC, MEP, } \\
\text { Ministry of } \\
\text { Science and } \\
\text { Technology, } \\
\text { Ministry of } \\
\text { Finance, } \\
\text { Ministry of } \\
\text { Construction, } \\
\text { Ministry of } \\
\text { Agriculture, } \\
\text { Ministry of } \\
\text { Education, } \\
\text { Ministry of } \\
\text { Land and } \\
\text { Resources, } \\
\text { State } \\
\text { Administration } \\
\text { of Taxation, } \\
\text { State Quality } \\
\text { Inspection } \\
\text { Administration }\end{array}$ & $\begin{array}{l}\text { Issued by } \\
\text { General } \\
\text { Office of } \\
\text { the State } \\
\text { Council, } \\
\text { No. } 100\end{array}$ & Dec. 17, 2003 & $\begin{array}{l}\text { In order to } \\
\text { implement the } \\
\text { Laws for } \\
\text { Promoting CP } \\
\text { of People's } \\
\text { Republic of } \\
\text { China, } \\
\text { accelerate the } \\
\text { development } \\
\text { of CP, } \\
\text { increase } \\
\text { resource use } \\
\text { efficiency, } \\
\text { decrease } \\
\text { pollution, } \\
\text { protect } \\
\text { environment } \\
\text { and human } \\
\text { health, and } \\
\text { realize the } \\
\text { sustainable } \\
\text { development } \\
\text { of economy } \\
\text { and society. }\end{array}$ & Guiding policies \\
\hline $\begin{array}{l}\text { Interim } \\
\text { Procedures } \\
\text { for Auditing } \\
\text { CP }\end{array}$ & $\begin{array}{l}\text { NDRC and } \\
\text { SEPA }\end{array}$ & $\begin{array}{l}\text { Issued by } \\
\text { SEPA, } \\
\text { No. } 16\end{array}$ & Aug. 16, 2004 & $\begin{array}{l}\text { In order to } \\
\text { fully } \\
\text { implement CP } \\
\text { and regulate }\end{array}$ & Guiding policies \\
\hline
\end{tabular}




\section{elsevier_JCLP_7561}

\begin{tabular}{|c|c|c|c|c|c|}
\hline & & & & $\begin{array}{l}\text { audit } \\
\text { behaviours of } \\
\mathrm{CP}\end{array}$ & \\
\hline $\begin{array}{l}\text { Methods for } \\
\text { Utilizing the } \\
\text { Exclusive } \\
\text { Funds for CP } \\
\text { Subsidized } \\
\text { by Central } \\
\text { Government }\end{array}$ & $\begin{array}{l}\text { Ministry of } \\
\text { Finance }\end{array}$ & No.343 & Oct.13, 2004 & $\begin{array}{l}\text { In order to } \\
\text { regulate the } \\
\text { utilization and } \\
\text { management } \\
\text { of the } \\
\text { exclusive } \\
\text { funds for CP } \\
\text { subsidized by } \\
\text { Central } \\
\text { Government }\end{array}$ & Incentive policies \\
\hline $\begin{array}{l}\text { Notice of } \\
\text { Regulating } \\
\text { the Audit } \\
\text { Process of } \\
\text { CP for Key } \\
\text { Firms }\end{array}$ & SEPA & No. 151 & Dec. 13, 2005 & $\begin{array}{l}\text { In order to } \\
\text { carry out the } \\
\text { CP audit of } \\
\text { the key firms } \\
\text { normatively } \\
\text { and orderly in } \\
\text { the whole } \\
\text { country. }\end{array}$ & Regulating policies \\
\hline $\begin{array}{l}\text { Notice of } \\
\text { Further } \\
\text { Enhancing } \\
\text { the CP audit } \\
\text { of Key Firms }\end{array}$ & SEPA & No.60 & Jul. 1, 2008 & $\begin{array}{l}\text { In order to } \\
\text { further realize } \\
\text { the importance } \\
\text { of CP in } \\
\text { reducing } \\
\text { pollution, and } \\
\text { enhance the } \\
\mathrm{CP} \text { audit of } \\
\text { the key firms. }\end{array}$ & Comprehensive policies \\
\hline $\begin{array}{l}\text { Notice for } \\
\text { Further } \\
\text { Advancing } \\
\text { CP of Key } \\
\text { Firms }\end{array}$ & SEPA & No.54 & Apr. 22, 2010 & $\begin{array}{l}\text { In order to, } \\
\text { deeply and } \\
\text { firmly, } \\
\text { advance CP in } \\
\text { key firms }\end{array}$ & Comprehensive policies \\
\hline $\begin{array}{l}\text { Decision for } \\
\text { Modifying the } \\
\text { Laws for } \\
\text { Promoting } \\
\text { CP of } \\
\text { People's } \\
\text { Republic of } \\
\text { China }\end{array}$ & NPCSC & $\begin{array}{l}\text { Decree of } \\
\text { the } \\
\text { President } \\
\text { of the } \\
\text { People's } \\
\text { Republic } \\
\text { of China, } \\
\text { No.54 }\end{array}$ & Feb. 29, 2012 & $\begin{array}{l}\text { In order to } \\
\text { further } \\
\text { advance CP in } \\
\text { China, } \\
\text { enhance the } \\
\text { construction of } \\
\text { audit } \\
\text { institution of } \\
\mathrm{CP} \text {, regulate } \\
\text { the audit team } \\
\text { of CP, and } \\
\text { perfect the } \\
\text { management } \\
\text { system of CP. }\end{array}$ & Guiding policies \\
\hline $\begin{array}{l}\text { General } \\
\text { Principles for } \\
\text { Compiling } \\
\text { the } \\
\text { Evaluation }\end{array}$ & $\begin{array}{l}\text { NDRC, MEP, } \\
\text { Ministry of } \\
\text { Industry and } \\
\text { Information }\end{array}$ & $\begin{array}{l}\text { Release } \\
\text { of NDRC, } \\
\text { No. } 33\end{array}$ & Jun. 5, 2013 & $\begin{array}{l}\text { In order to } \\
\text { accelerate the } \\
\text { formulation of } \\
\text { a systematic } \\
\text { and unified }\end{array}$ & Guiding policies \\
\hline
\end{tabular}




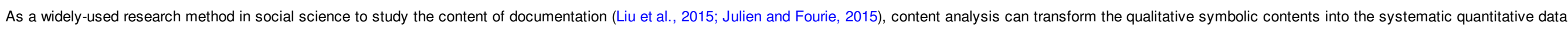

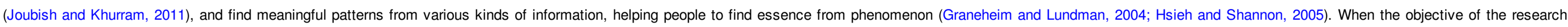





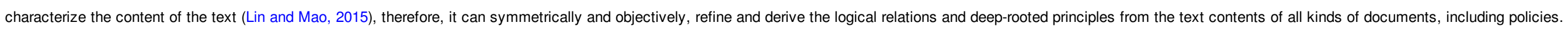

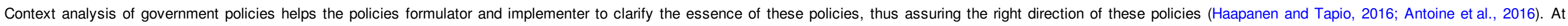



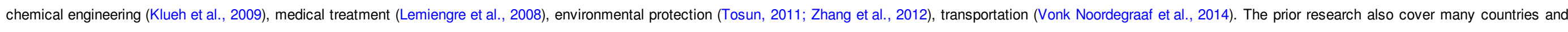

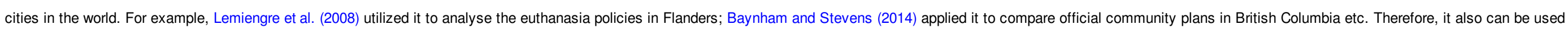
to refine and derive the statistical principles about $\mathrm{CP}$ in related regulations and policies.

According to content analysis literature (e.g. Williams and Plouffe, 2007; Vallet-Bellmunt et al., 2011; Wickens et al., 2013), content analysis is normally undertaken with the following procedures.

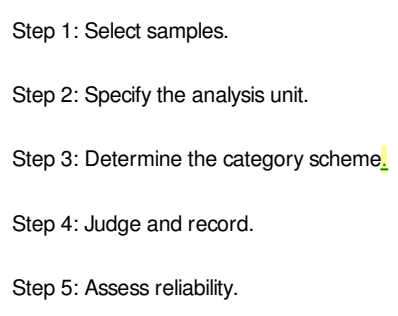

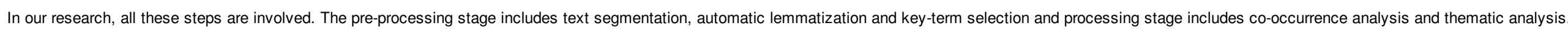

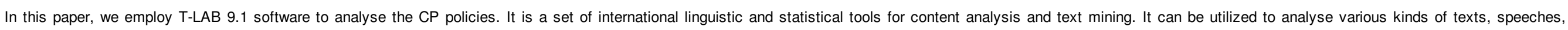

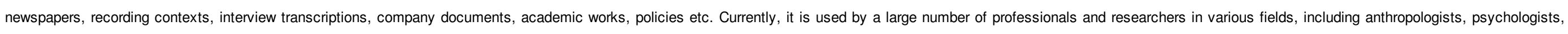

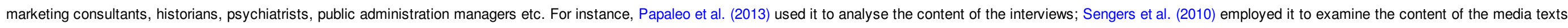

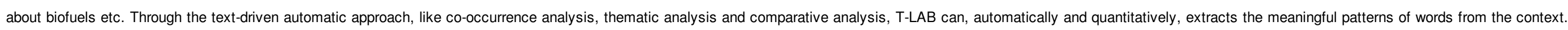


the text contents without being influenced by personal opinions. Meanwhile, tables and charts resulted from the software can be easily browsed and interpreted, increasing the accuracy and reliability of the results.

\section{Research findings}

We employ two functions of T-LAB software for content analysis, which are word associations and thematic analysis of elementary contexts, to derive the insights of CP policies.

\subsection{Word associations}

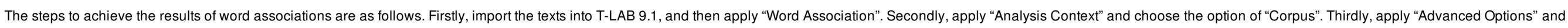

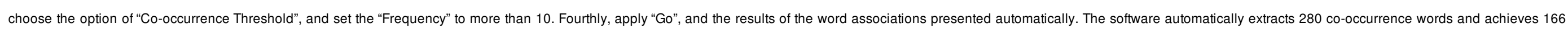

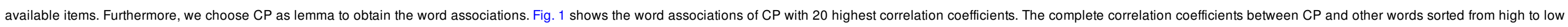
are presented in Appendix 1. 




Fig. 1 Word associations of CP with 20 highest correlation coefficients (the cosine values).



\subsubsection{Audit}

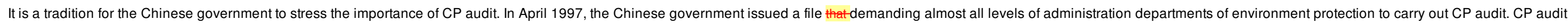



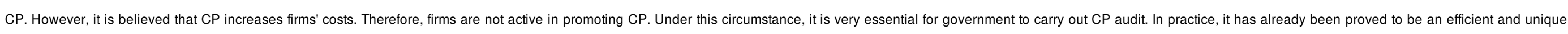

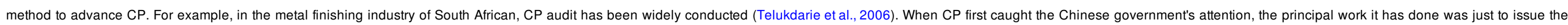



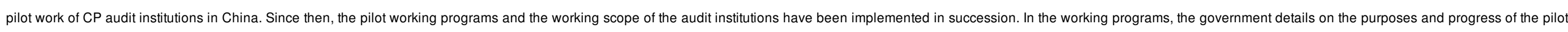

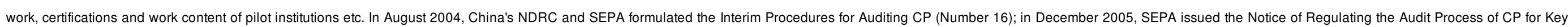

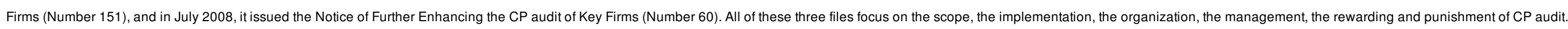

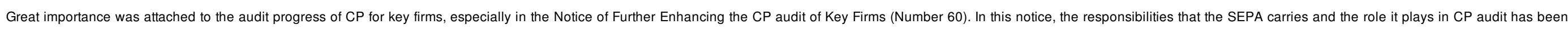
specified. It not only integrates the $\mathrm{CP}$ audit with existing environment management system, but also proposes the standardized management measures for audit institutions of $\mathrm{CP}$.

\subsubsection{Implementation}







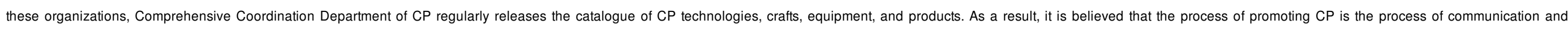

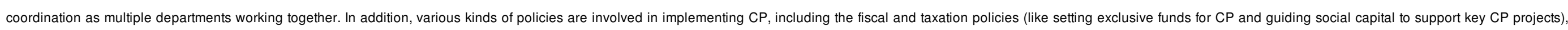


government procurement policies (like giving priority to the products of CP) etc.

\subsubsection{Environmental}



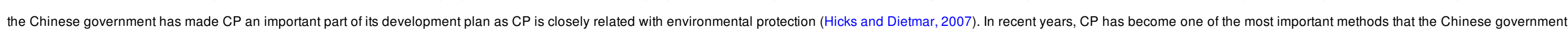




\section{elsevier_JCLP_7561}

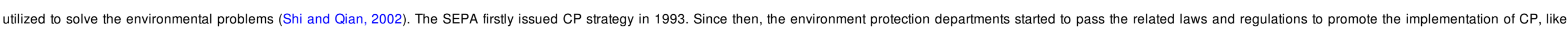

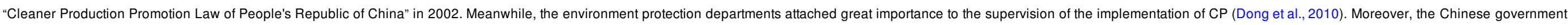
included CP in the environmental protection act, which further demonstrateding that Chinese government put a high value on CP.

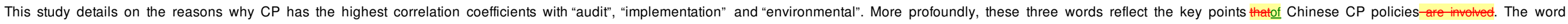





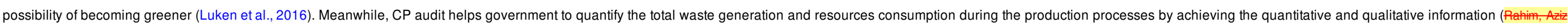



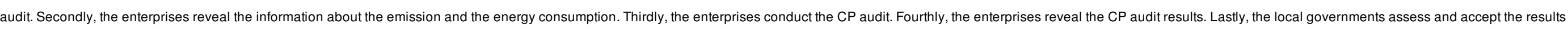

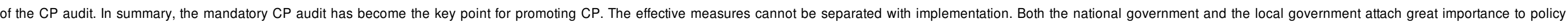



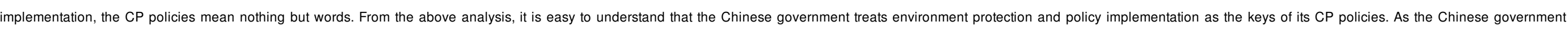
specifically highlights the importance of the mandatory $\mathrm{CP}$ audit, it is reasonable to assume that CP policies in China give specific priority to constraint and regulating policies.

\subsection{Thematic analysis of elementary contexts}

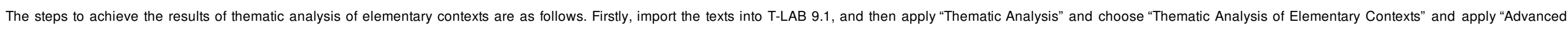

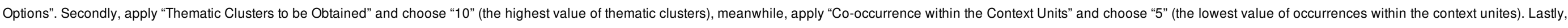
apply "Go", and the results of the thematic analysis of elementary contexts presented automatically, shown in Fig. 2. Appendices $2-5$ present the key items of every main subject.



Fig. 2 Results of thematic analysis of the CP policies.

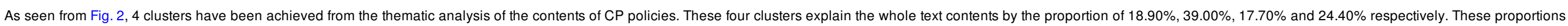

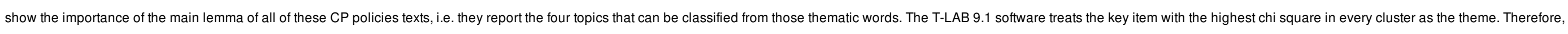
the four themes of CP policies in China are "Pilot", "Indicator", "People" and "List", presented in Appendices 2-5. The explanations for all the four themes are given in the following.

\subsubsection{Pilot}

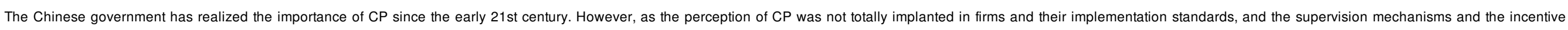






\section{elsevier_JCLP_7561}



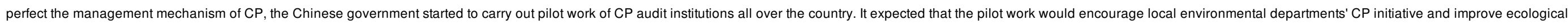

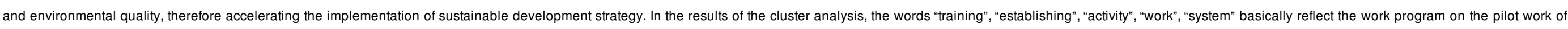




"incentive" reflect the main aims of the CP pilot work, for example, increasing CP "awareness" and "incentive", "winning public support" for CP, and getting firms to be "engaged" in CP.

\subsubsection{List(This should be section 4.2.4.)}

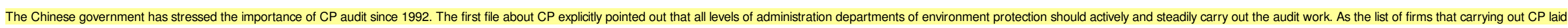





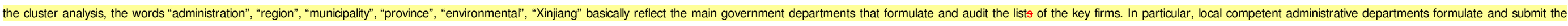




"report" of audit results to the competent administrative departments. (This paragraph under List should be moved to 4.2.4.)

\subsubsection{People}



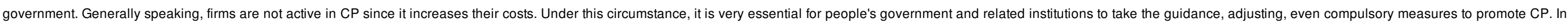

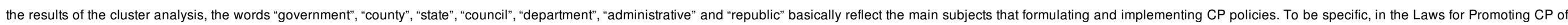

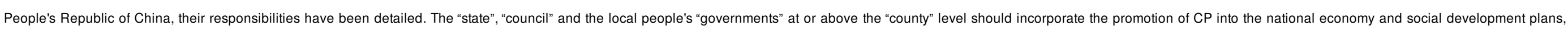

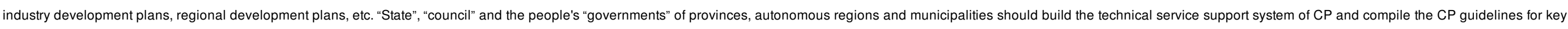

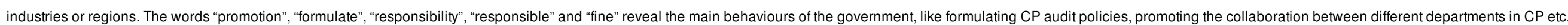

\subsubsection{Indicator(This should be section 4.2.2.)}



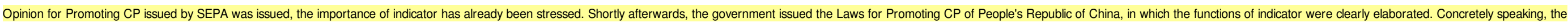



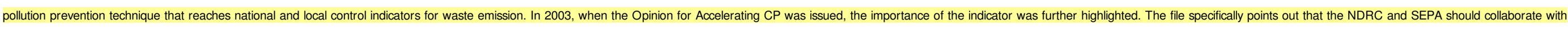





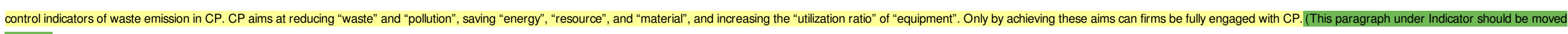
to 4.2.2.)

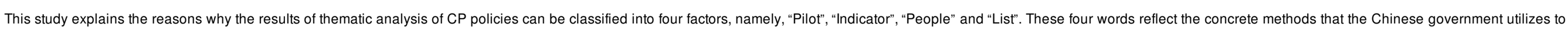






people's government in China intimately work together to formulate, to promote and to implement the CP policies. 


\section{elsevier_JCLP_7561}

\section{Discussions}

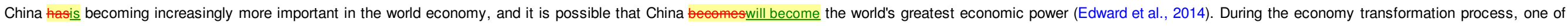


years, but the economy progresses arealso accompanied by serious environment problems (Zhang et al., 2013).

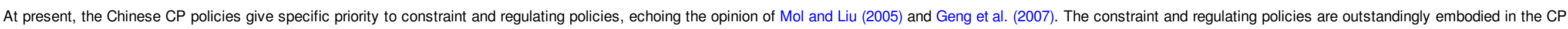



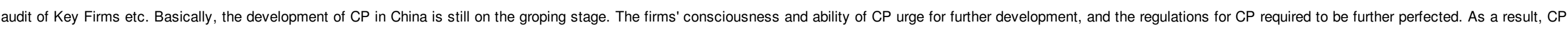

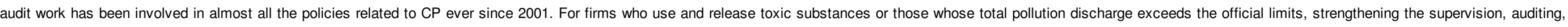

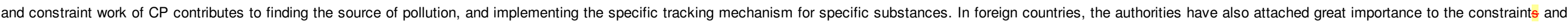





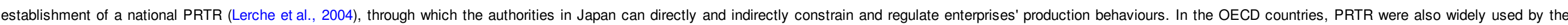

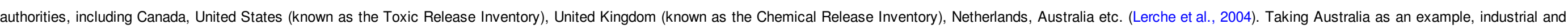



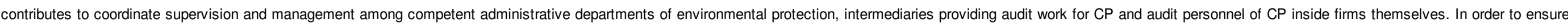

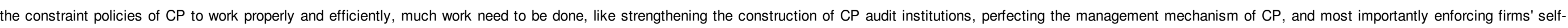


the real "threat" can firms fully adopt self-disciplined behaviours in CP. At this point, firms will actively and comprehensively promote CP, and use CP as a competitive advantage to compete with other firms

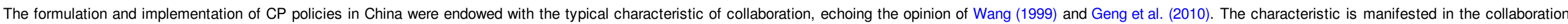





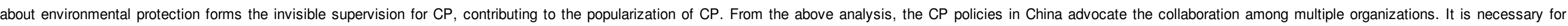



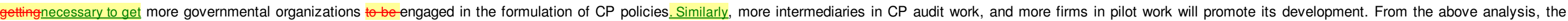



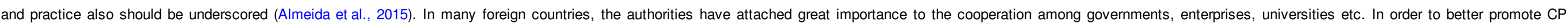

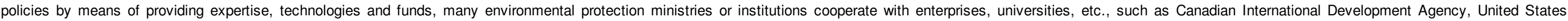






also been stressed, which means that it is essential for the governments to cooperate with non-governmental organizations in order to promote CP.

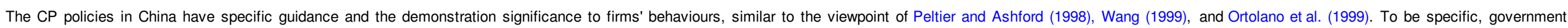

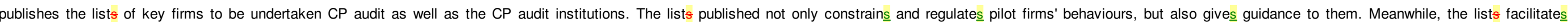



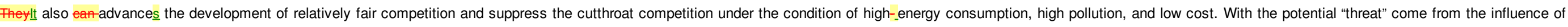

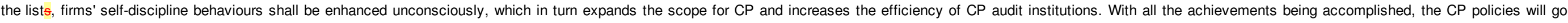








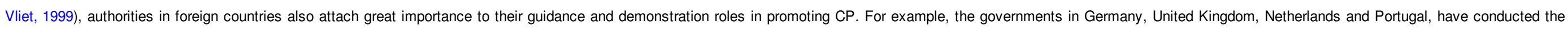

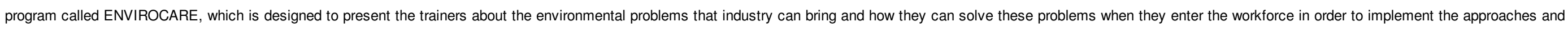



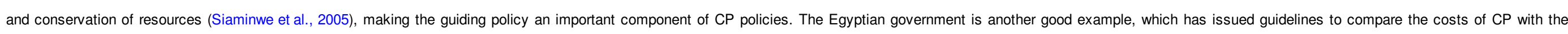


As a result, they are trying to guide enterprises to carry out $\mathrm{CP}$ voluntarily rather than using the mandatory methods to force them to promote $\mathrm{CP}$.

\section{Conclusions}

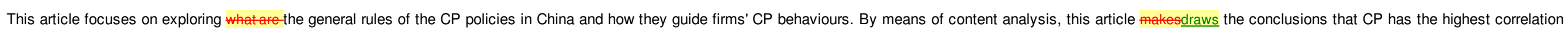





\subsection{Research implications}









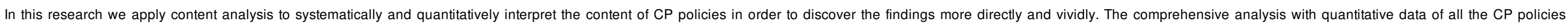
published in China contributes to discover the essence of CP policies from the contents point of view.


and then guide them to take effective measures.

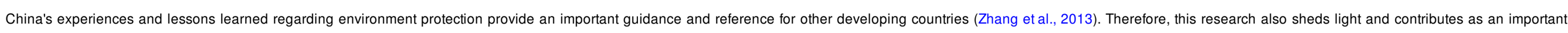
general reference of $\mathrm{CP}$ policies for governments and firms in the emerging countries.

\subsection{Limitations and future research}



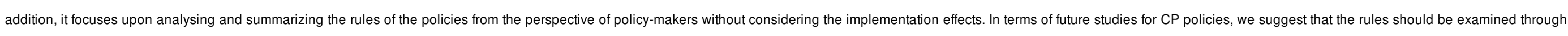
comparing and contrasting from the perspectives of the government, industries and experts.

\section{Acknowledgements}

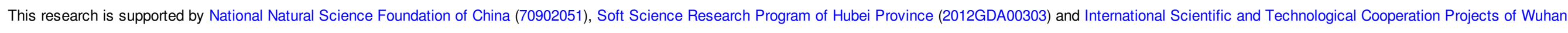
City (2014030709020311).

\section{Appendix 1. Correlation coefficients of CP.}

\begin{tabular}{|c|c|c|c|c|c|}
\hline LEMMA & COEFFa & C.E. $(A)^{b}$ & C.E. $(A B)^{c}$ & & $\mathrm{CHI} 2^{\mathrm{d}}$ \\
\hline Audit & 0.666 & 148 & 145 & 62.184 & \\
\hline Implementation & 0.594 & 117 & 115 & 45.452 & \\
\hline
\end{tabular}




\section{elsevier_JCLP_7561}

\begin{tabular}{|c|c|c|c|c|}
\hline Environmental & 0.589 & 174 & 139 & 3.105 \\
\hline Department & 0.581 & 169 & 135 & 2.952 \\
\hline Protection & 0.544 & 157 & 122 & 0.673 \\
\hline Enterprise & 0.53 & 147 & 115 & 0.926 \\
\hline Level & 0.467 & 106 & 86 & 2.446 \\
\hline Management & 0.423 & 63 & 60 & 15.617 \\
\hline Development & 0.418 & 71 & 63 & 8.101 \\
\hline Work & 0.403 & 56 & 54 & 15.308 \\
\hline Key & 0.396 & 67 & 58 & 5.292 \\
\hline Implement & 0.396 & 54 & 52 & 14.496 \\
\hline National & 0.385 & 76 & 60 & 0.604 \\
\hline Technology & 0.374 & 86 & 62 & 0.665 \\
\hline State & 0.372 & 76 & 58 & 0.036 \\
\hline System & 0.367 & 49 & 46 & 10.139 \\
\hline Promote & 0.367 & 47 & 45 & 11.736 \\
\hline Industry & 0.362 & 62 & 51 & 1.807 \\
\hline Promotion & 0.349 & 39 & 39 & 13.959 \\
\hline Carryout & 0.349 & 39 & 39 & 13.959 \\
\hline Local & 0.348 & 67 & 51 & 0.018 \\
\hline Relevant & 0.339 & 48 & 42 & 4.23 \\
\hline Government & 0.333 & 57 & 45 & 0.43 \\
\hline strengthen & 0.326 & 36 & 35 & 10.054 \\
\hline Training & 0.321 & 33 & 33 & 11.63 \\
\hline Region & 0.32 & 44 & 38 & 3.146 \\
\hline Emission & 0.319 & 65 & 46 & 0.917 \\
\hline Focus & 0.317 & 38 & 35 & 6.239 \\
\hline Plan & 0.317 & 36 & 34 & 7.65 \\
\hline Evaluation & 0.308 & 38 & 34 & 4.421 \\
\hline People & 0.3 & 50 & 38 & 0.009 \\
\hline Develop & 0.298 & 43 & 35 & 0.907 \\
\hline Organization & 0.296 & 32 & 30 & 6.247 \\
\hline Support & 0.296 & 30 & 29 & 7.834 \\
\hline Project & 0.295 & 39 & 33 & 1.94 \\
\hline
\end{tabular}


elsevier_JCLP_7561

\begin{tabular}{|l|l|l|l|l|}
\hline Agency & 0.287 & 32 & 29 & 4.293 \\
\hline Pollution & 0.282 & 51 & 36 & 0.747 \\
\hline Administrative & 0.279 & 61 & 39 & 5.123 \\
\hline Production & 0.278 & 75 & 43 & 16.194 \\
\hline Province & 0.276 & 30 & 27 & 3.681 \\
\hline Acceptance & 0.274 & 26 & 25 & 6.4 \\
\hline Report & 0.271 & 31 & 27 & 2.442 \\
\hline Supervision & 0.271 & 31 & 27 & 2.442 \\
\hline Technical & 0.271 & 31 & 27 & 2.442 \\
\hline Economic & 0.271 & 41 & 31 & 0.001 \\
\hline Process & 0.269 & 50 & 34 & 1.709 \\
\hline Organize & 0.268 & 25 & 24 & 6.048 \\
\hline Pollutant & 0.267 & 60 & 37 & 7.195 \\
\hline Requirement & 0.263 & 26 & 24 & 4.241 \\
\hline Service & 0.263 & 33 & 27 & 0.779 \\
\hline
\end{tabular}

${ }^{a} \mathrm{COEFF}=$ value of the selected index.

${ }^{b}$ C.E. $(A)=$ total amount of elementary contexts $(E C)$ that contains the selected lemma $(A)$.

${ }^{\circ}$ C.E. $(A B)=$ total amount of elementary contexts $(E C)$ where lemmas " $A$ " and "B" are associated (co-occurrences).

${ }^{\mathrm{d}} \mathrm{CH} 2 \mathrm{l}=$ chi square value concerning the co-occurrence significance.

\section{Appendix 2. Cluster 1 obtained from the thematic analysis of elementary contexts.}

\begin{tabular}{|c|c|c|c|}
\hline LEMMA & $\mathrm{CHI} 2$ & EC IN CLUSTER & EC IN TOTAL \\
\hline Pilot & 53.566 & 21 & 28 \\
\hline Establishing & 45.582 & 15 & 18 \\
\hline Training & 44.867 & 24 & 38 \\
\hline $\mathrm{CP}$ & 41.417 & 190 & 641 \\
\hline SME & 40.337 & 10 & 10 \\
\hline Activity & 36.299 & 9 & 9 \\
\hline Work & 35.555 & 31 & 62 \\
\hline System & 32.918 & 33 & 70 \\
\hline Leadership & 30.896 & 9 & 10 \\
\hline Cost & 30.317 & 11 & 14 \\
\hline Fund & 29.75 & 15 & 23 \\
\hline Engage & 28.226 & 7 & 7 \\
\hline
\end{tabular}




\begin{tabular}{|l|l|l|l|}
\hline Publicity & 28.226 & 7 & 7 \\
\hline Awareness & 26.929 & 8 & 9 \\
\hline Certification & 26.589 & 10 & 13 \\
\hline Audit & 23.685 & 81 & 254 \\
\hline Support & 21.95 & 18 & 35 \\
\hline Information & 21.48 & 11 & 17 \\
\hline River & 20.157 & 5 & 5 \\
\hline Incentive & 19.901 & 9 & 13 \\
\hline
\end{tabular}

Appendix 3. Cluster 2 obtained from the thematic analysis of elementary contexts.

\begin{tabular}{|c|c|c|c|}
\hline LEMMA & $\mathrm{CHI} 2$ & EC IN CLUSTER & EC IN TOTAL \\
\hline Indicator & 118.943 & 70 & 72 \\
\hline Waste & 79.136 & 48 & 50 \\
\hline Product & 61.201 & 66 & 87 \\
\hline Energy & 57.525 & 46 & 54 \\
\hline Process & 55.885 & 48 & 58 \\
\hline Utilization & 50.104 & 37 & 42 \\
\hline Resource & 48.945 & 58 & 79 \\
\hline Equipment & 46.46 & 38 & 45 \\
\hline Material & 42.64 & 49 & 66 \\
\hline Production & 36.208 & 60 & 91 \\
\hline Project & 36.049 & 41 & 55 \\
\hline Water & 32.893 & 27 & 32 \\
\hline Value & 32.282 & 18 & 18 \\
\hline Method & 26.892 & 15 & 15 \\
\hline Evaluation & 26.477 & 39 & 57 \\
\hline Chemical & 25.564 & 18 & 20 \\
\hline Reference & 23.371 & 15 & 16 \\
\hline Design & 23.301 & 13 & 13 \\
\hline Impact & 22.764 & 18 & 21 \\
\hline Pollution & 22.393 & 37 & 56 \\
\hline
\end{tabular}

Appendix 4. Cluster 3 obtained from the thematic analysis of elementary contexts. 
elsevier_JCLP_7561

\begin{tabular}{|c|c|c|c|}
\hline LEMMA & $\mathrm{CH} 2$ & EC IN CLUSTER & EC IN TOTAL \\
\hline People & 98.278 & 38 & 54 \\
\hline Promotion & 90.517 & 36 & 52 \\
\hline Government & 73.496 & 37 & 61 \\
\hline County & 68.883 & 24 & 32 \\
\hline Council & 65.223 & 32 & 52 \\
\hline State & 51.725 & 46 & 100 \\
\hline Economy & 42.378 & 13 & 16 \\
\hline Science & 38.201 & 11 & 13 \\
\hline Department & 37.105 & 80 & 240 \\
\hline Cooperation & 35.667 & 8 & 8 \\
\hline Agriculture & 35.667 & 8 & 8 \\
\hline Formulate & 35.667 & 8 & 8 \\
\hline Responsibility & 34.377 & 12 & 16 \\
\hline Fine & 31.205 & 7 & 7 \\
\hline Yuan & 31.205 & 7 & 7 \\
\hline Social & 29.646 & 9 & 11 \\
\hline Responsible & 29.071 & 15 & 25 \\
\hline Administrative & 27.99 & 32 & 77 \\
\hline Violation & 26.401 & 10 & 14 \\
\hline Republic & 22.525 & 9 & 13 \\
\hline
\end{tabular}

\section{Appendix 5. Cluster 4 obtained from the thematic analysis of elementary contexts.}

\begin{tabular}{|c|c|c|c|}
\hline LEMMA & $\mathrm{CHI} 2$ & EC IN CLUSTER & EC IN TOTAL \\
\hline List & 133.791 & 57 & 64 \\
\hline Administration & 66.181 & 35 & 44 \\
\hline Region & 63.151 & 36 & 47 \\
\hline Municipality & 55.888 & 24 & 27 \\
\hline Province & 51.64 & 25 & 30 \\
\hline Autonomous & 45.816 & 24 & 30 \\
\hline Company & 45.369 & 29 & 40 \\
\hline Publish & 41.384 & 31 & 46 \\
\hline Protection & 39.751 & 83 & 179 \\
\hline
\end{tabular}




\section{elsevier_JCLP_7561}

\begin{tabular}{|c|c|c|c|}
\hline Audit & 37.496 & 108 & 254 \\
\hline Major & 31.566 & 25 & 38 \\
\hline Medium & 30.508 & 16 & 20 \\
\hline Report & 29.716 & 25 & 39 \\
\hline Separately & 28.593 & 10 & 10 \\
\hline Submit & 28.593 & 10 & 10 \\
\hline Environmental & 26.926 & 94 & 231 \\
\hline Reform & 26.716 & 22 & 34 \\
\hline Corps & 24.208 & 10 & 11 \\
\hline Xinjiang & 24.208 & 10 & 11 \\
\hline Notice & 22.869 & 8 & 8 \\
\hline
\end{tabular}

\section{Uneited references}

Gina, 2015; Greg and Lestey, 2007; duan al., 2014; Yong al, 2010; Yoshiakietal., 2012.

\section{References}

Almeida C.M., Agostinho F., Giannetti B.F. and Huisingh D., Integrating cleaner production into sustainability strategies, an introduction to this special volume, J. Clean. Prod. 96, 2015, 1-9.

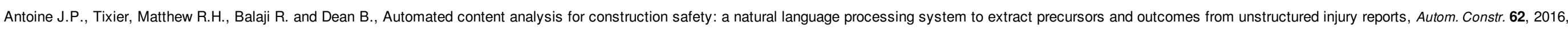
$45-56$.

Baynham M. and Stevens M., Are we planning effectively for climate change? an evaluation of official community plans in British Columbia, J. Environ. Plan. Manag. 57, $2014,557-587$.

Bai Y.J., Yin J., Yuan Y., Guo Y.J. and Song D.N., An innovative system for promoting cleaner production: mandatory cleaner production audits in China, J. Clean. Prod. 108, 2015, 883-890.

Blackman A., Small Firms and the Environment in Developing Countries, Collective Impacts, Collective Action, 2006, Economic Development and Cultural Change; Washington DC, USA.

Bonilla S.H., Almeida C.M., Giannetti B.F. and Huisingh D., The roles of cleaner production in the sustainable development of modern societies, an introduction to this special issue, J. Clean. Prod. 118, $2010,1-5$.

Brown G. and Stone L., Cleaner production in New Zealand: taking stock, J. Clean. Prod. 15 (8-9), 2007, 716-728.

Butnaru G.I., The method of ethnographic and content analysis in determining development factors of economic and managerial tourism performance, Proced. Econ. Financ. 20, $2015,104-111$.

Chang I.S., Wu J., Qiao H.M. and Zhang Z.L., The spatio-temporal approach to regional analysis on cleaner production in China, Renew. Sustain. Energy Rev. 52, 2015, 1491-1503.

Coakley T., The ENVIROCARE CD-ROM—cleaner production training for vocational students, J. Clean. Prod. 11 (5), 2003, 511-517.

D'Agostino A.L., et al., What's the state of energy studies research? a content analysis of three leading journals from 1999 to 2008, Energy 36 (1), $2011,508-519$.

Dong X.Q., Li C.L., Li J., Wang J. and Huang W.T., A game-theoretic analysis of implementation of cleaner production policies in the Chinese electroplating industry, Resour. Conserv. Recycl. 54 (12), 2010, 1442-1448.

Edward L., Martin W. and Zeng C., Do Chinese government subsidies affect firm value? accounting, Organ. Soc. 39 (3), 2014, 149-169.

Frijns J. and Vliet B., Small-scale industry and Cleaner Production Strategies, World Dev. 27, 1999, 967-983.

Geng Y., Haight M. and Zhu Q.H., Empirical analysis of eco-industrial development in China, Sustain. Dev. 15 (2), 2007, 121-133. 


\section{elsevier_JCLP_7561}

Geng Y., Wang X., Zhu Q. and Zhao H., Regional initiatives on promoting cleaner production in China: a case of Liaoning, J. Clean. Prod. 18 (15), 2010, 1502-1508.

Gina l.B., The method of ethnographic and content analysis in determining development factors of economie and managerial tourism performanee, Proced. Econ. Financ. 20,2015, 104-111.

Glavic P. and Lukman R., Review of sustainability terms and their definitions, J. Clean. Prod. 18, 2007, 1875-1885.

Gombault M. and Versteege S., Cleaner production in SMEs through a partnership with local authorities, successes from the Netherlands, J. Clean. Prod. 7, 1999, 249-261.

Graneheim U.H. and Lundman B., Qualitative content analysis in nursing research: concepts, procedures and measures to achieve trustworthiness, Nurse Educ. Today 24, $2004,105-112$.

Greg B.-and Lestey S., Cleaner produetion in New Zealand, taking stock, J. Clean. Prod. 15,2007, 716-728.

Guo H.C., Chen B., Yu X.L., Huang G.H., Liu L. and Nie X.H., Assessment of cleaner production options for alcohol industry of China, a study in the Shouguang Alcohol Factory, J. Clean. Prod. 14, $2006,94-103$.

Haapanen L. and Tapio P., Economic growth as phenomenon, institution and ideology: a qualitative content analysis of the 21st century growth critique, J. Clean. Prod. 112, 2016, 3492-3503.

Hamed M.M. and Mahgary Y.E., Outline of a national strategy for cleaner production, the case of Egypt, J. Clean. Prod. 12, 2004, 327-336.

Hendryx M., Luo J. and Chen B.C., Total and cardiovascular mortality rates in relation to discharges from toxics release inventory sites in the United States, Environ. Res. $133,2014,36-41$.

Hicks C. and Dietmar R., Improving cleaner production through the application of environmental management tools in China, J. Clean. Prod. 15, 2007, 395-408.

Hong J.L. and Li X.Z., Speeding up cleaner production in China through the improvement of cleaner production audit, J. Clean. Prod. 40, 2013, 129-135.

Hsieh H.F. and Shannon S.E., Three approaches to qualitative content analysis, Qual. Health Res. 15, 2005, 1277-1288.

Huang Y., Luo J. and Xia B., Application of cleaner production as an important sustainable strategy in the ceramic tile plant - a case study in Guangzhou, China, J. Clean. Prod. 43 (3), $2013,113-121$.

Jin J.S., Japanese agricultural environmental policies and the implications, Contemp. Econ. Jpn. 173 (5), 2010, 60-64.

Jobe M.M., The power of information: the example of the U.S. toxics release inventory, J. Gov. Inf. 26 (3), 1999, 287-295.

Joubish M.F. and Khurram M.A., Outlook on some concepts in the curriculum of social studies, World Appl. Sci. J. 12 (9), 2011, $1374-1377$.

Julien H. and Fourie I., Reflections of affect in studies of information behavior in HIV/AIDS contexts: an exploratory quantitative content analysis, Libr. Inf. Sci. Res. 37 (1), 2015 , 3-9.



J. Clean. Prod. 108,-2014, 1-10.

Ju-Pak K., Content dimensions of web advertising: a cross-national comparison, Int. J. Advert. 18, 1999, 207-231.

Khalili N.R., Duecker S., Ashton W. and Chavez F., From cleaner production to sustainable development, the role of academia, J. Clean. Prod. 96, $2014,1-14$.

Khuriyati N. and Wagiman Kumalasari D., Cleaner production strategy for improving environmental performance of small scale cracker industry, Agric. Agric. Sci. Proced. 3, $2015,102-107$.

Klueh U.H., Pastor G. and Segura A., Policies to improve the local impact from hydrocarbon extraction: observations on West Africa and possible lessons for Central Asia, Energy Policy 37 (3), $2009,1128-1144$.

Kolominskas C. and Sullivan R., Improving cleaner production through pollutant release and transfer register reporting processes, J. Clean. Prod. 12 (7), $2004,713-724$.

Konar S. and Cohen M.A., Information as regulation: the effect of community right to know laws on toxic emissions, J. Environ. Econ. Manag. 32 (1), 1997, 109-124.

Kong G. and White R., Toward cleaner production of hot dip galvanizing industry in China, J. Clean. Prod. 18, 2010, 1092-1099.

Li H., Ni J., Liu W. and Zhu Y., Cleaner production alternatives for saponin industry by recycling starch, Resour. Conserv. Recycl. 54 (12), $2010,1145-1151$. 


\section{elsevier_JCLP_7561}

Lemiengre J., et al., How do hospitals deal with euthanasia requests in Flanders, Belgium? a content analysis of policy documents, Patient Educ. Couns. 71 (2), $2008,293-301$.

Lerche D., et al., Ranking of chemical substances based on the Japanese Pollutant Release and Transfer Register using partial order theory and random linear extensions, Chemosphere 55 (7), 2004, 1005-1025.

Liao Z., The evolution of wind energy policies in China (1995-2014): an analysis based on policy instruments, Renew. Sustain. Energy Rev. 56, $2016,464-472$.

Lin L. and Mao P.C., Food for memories and culture a content analysis study of food specialties and souvenirs, J. Hosp. Tour. Manag. 22, 2015, 19-29.

Lingard J., Agricultural Subsidies and Environmental Change, 2002, University of Newcastle upon Tyne, Newcastle upon Tyne, UK. Encyclopedia of Global Environmental Change. John Wiley \& Sons, Ltd.

Liu Y., Sustainable competitive advantage in turbulent business environments, Int. J. Prod. Res. 51, 2013, 2821-2841.

Liu Y. and Liang L., Evaluating and developing resource-based operations strategy for competitive advantage: an exploratory study of Finnish high-tech manufacturing industries, Int. J. Prod. Res. 53, 2015, 1019-1037.

Liu Y., Liu F.Y., Zhang J.F. and Gao J.B., Insights into the nature of food safety issues in Beijing through content analysis of an Internet database of food safety incidents in China, Food Control 51, 2015, 206-211.

Luo L.G., Wang Y. and Qin L.H., Incentives for promoting agricultural clean production technologies in China, J. Clean. Prod. 74, 2014, 54-61.

Luken R.A., Van Berkel R., Leuenberger H. and Schwager P., A 20-year retrospective of the National Cleaner Production Centres programme, J. Clean. Prod. 112, 2016, 1165-1174.

Mol A. and Liu Y., Institutionalising cleaner production in China, the cleaner production promotion law, Int. J. Environ. Sustain. Dev. 4 (3), 2005, 227-245.

Nyaupane N.P. and Gillespie J.M., Louisiana crawfish farmer adoption of best management practices, Soil. Water Conserv. 66 (1), 2011, 61-70.

Ortolano L., Cushing K.K. and Warren K.A., Cleaner production in China, Environ. Impact Assess. Rev. 19, 1999, 431-436.

Papaleo Bruno, Cangiano Giovanna and Calicchia Sara, Occupational safety and health professionals' training in Italy, Qualitative evaluation using T-LAB, J. Workplace Learn. 25 (4), $2013,247-263$.


Prod. 6, 1998, 111-117.

Petek J. and Glavic P., Improving the sustainability of regional cleaner production programs, Resour. Conserv. Recycl. 29, 2000, 19-31.



Ren X., Cleaner production in China's pulp and paper industry, J. Clean. Prod. 6, 1998, 349-355.

Richardson C.W., Bucks D.A. and Sadler E.J., The conservation effects assessment project benchmark watersheds, synthesis of preliminary findings, Soil Water Conserv. 63 (6), $2008,590-604$.

Schramm W., New findings on the generation of waste and emissions, and a modified cleaner production assessment approach-illustrated by leather production, J. Clean. Prod. 5 (4), 1997, 291-300.

Sengers F., Raven R.P. and Van V., From riches to rags, Biofuels, media discourses, and resistance to sustainable energy technologies, Energy Policy 38, 2010, 5013-5027.

Shi H., Peng S.Z., Liu Y. and Zhong P., Barriers to the implementation of cleaner production in Chinese SMEs, government, industry and expert stakeholders' perspectives, J. Clean. Prod. 16, 2008, 842-852.

Shi L. and Qian Y., The review and perspective of cleaner production: the state of the art. China Pollution, Resour. Environ. 12 (2), 2002, 121-124.

Siaminwe L., Chinsembu K.C. and Syakalima M., Policy and operational constraints for the implementation of cleaner production in Zambia, J. Clean. Prod. 13 (10-11), 2005, 1037-1047.

Silvestre B.S. and Silva Neto R. e, Are cleaner production innovations the solution for small mining operations in poor regions? the case of Padua in Brazil, J. Clean. Prod. 84, 2014, 809-817.

Singh N., Zhao H. and Hu X., Cultural adaptation on the web: a study of American domestic and Chinese websites, J. Glob. Inf. Manag. 11, $2003,63-80$.

Telukdarie A., Buckley C. and Koefoed M., The importance of assessment tools in promoting cleaner production in the metal finishing industry, J. Clean. Prod. 14 (18), $2006,1612-1621$. 


\section{elsevier_JCLP_7561}

Tosun J., Political parties and marine pollution policy, exploring the case of Germany, Mar. Policy 35 (4), 2011, 536-541.

Thorpe B., How the Toxics Use Reduction Act continues to promote clean production Internationally, J. Clean. Prod. 19, 2011, 552-558.

Tseng M.L., Lin Y.H. and Chiu A.S.F., Fuzzy AHP-based study of cleaner production implementation in Taiwan PWB manufacturer, J. Clean. Prod. 17, 2009, 249-1256.

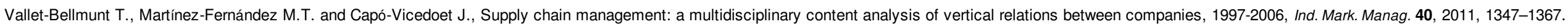

Vonk Noordegraaf D., Annema J.A. and van Wee B., Policy implementation lessons from six road pricing cases, Transp. Res. Part A Policy Pract. 59, $2014,172-191$.

Wang J., China's national cleaner production strategy, Environ. Impact Assess. Rev. 19, 1999, 437-456.

Wickens C.M., Wiesenthal D.L., Hall A. and Roseborough J.E.W., Driver anger on the information superhighway: a content analysis of online complaints of offensive driver behavior, Accid. Anal. Prev. 51, $2013,84-92$.

Williams B.C. and Plouffe C.R., Assessing the evolution of sales knowledge: a 20-year content analysis, Ind. Mark. Manag. 36, $2007,408-419$.

Xie J. and Sidney S., Environmental policy analysis, an environmental computable general-equilibrium approach for developing countries, J. Policy Model. 22, 2000, 453-489.



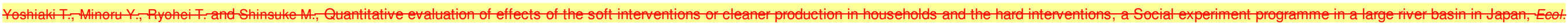
Indic. 20,2012, 282-294.

Yusup M.Z., Wan Mahmood W.H., Salleh M.R. and Ab Rahman M.N., The implementation of cleaner production practices from Malaysian manufacturers' perspectives, J. Clean. Prod. 108, 2015, 659-672.

Zhang B., Yang S.C. and Bi J., Enterprises' willingness to adopt/develop cleaner production technologies, an empirical study in Changshu, China, J. Clean. Prod. 40, $2013,62-70$.

Zhang H.M., Wang Q.W. and Simon R.M., Waste cooking oil as an energy resource, Review of Chinese policies, Renew. Sustain. Energy Rev. 16, 2012, 5225-5231.

Zhang J.Y., Jiang J.H. and Tian G.M., The potential of fertilizer management for reducing nitrous oxide emissions in the cleaner production of bamboo in China, J. Clean. Prod. 112, $2016,2536-2544$.

Zhang K. and Wen Z., Review and challenges of policies of environmental protection and sustainable development in China, J. Environ. Manag. 88, 2008, 1249-1261.

Zhou Y. and Zhao L., Impact analysis of the implementation of cleaner production for achieving the low-carbon transition for SMEs in the Inner Mongolian coal industry, J. Clean. Prod. 127, 2016, 418-424.

Zwetsloot G.I. and Geyer A., The essential elements for successful cleaner production programmes, J. Clean. Prod. 4 (1), 1996, 29-39.

\section{Footnotes}

${ }^{1}$ The SEPA became the Ministry of Environmental Protection (MEP) in 2008.

\section{Queries and Answers}


therefore not reliable in the long term.

Answer: That is fine.

Query: Please check the address for the corresponding author that has been added here, and correct if necessary.

Answer: Corrections were made.

Query: Please check the hierarchy of the section headings.

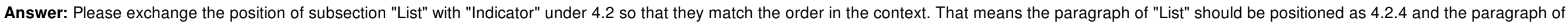
"Indicator" should be positioned as 4.2 .2 (see the instructions). We also added one sentence between section 4 and 4.1 to improve the readability. 


\section{elsevier_JCLP_7561}


Answer: Rahim and Raman, 2015 is the correct one cited in the text and also provided in the reference list. Rahim, Aziz and Raman, 2015 is incorrect and has been deleted.

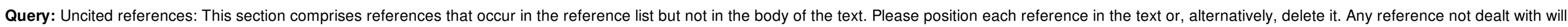
be retained in this section. Thank you.

Answer: All these were listed by mistake and deleted.

Query: Please confirm that given names and surnames have been identified correctly.

Answer: Yes


k.kumar.1@elsevier.com immediately prior to returning your corrections.

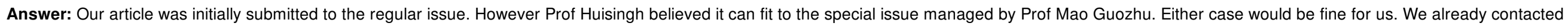
k.kumar.1@elsevier.com requesting to clarify in which channel it will be published but did not get any reply so far. 